DOI: $10.17951 / \mathrm{m} \cdot 2019.4 .39-52$

\begin{tabular}{lcr}
\hline & ANNALES \\
& UNIVERSITATIS MARIAE CURIE-SKŁODOWSKA & \\
LUBLIN - POLONIA & \\
VOL. IV & SECTIO M & 2019 \\
\hline
\end{tabular}

\author{
Magdalena Lesińska-Staszczuk \\ Maria Curie-Skłodowska University in Lublin \\ magdalena.lesinska-staszczuk@poczta.umcs.lublin.pl \\ ORCID ID: http://orcid.org/0000-0002-7372-8604
}

\title{
Women's rights in the light of the programmes of the victorious political parties in Poland's 2019 parliamentary elections
}

\section{Introduction}

Women's rights in the 21st century are an ever-present issue in public debate and are reflected in the electoral programmes of individual political parties. Both the right and the left side of the political scene promise equal rights of women and men in public life, counteraction to discrimination in respect of employment, support for families and provision of adequate health care.

The purpose of the article is to analyze the programmes of the parties victorious in the 2019 parliamentary elections in Poland in respect of how they address women's issues. In making an attempt at the comparison and description of the electoral programmes, the following question was asked: to what extent was the issue of women's rights reflected in the electoral programmes of individual political parties in Poland, and what promises were raised most often?

Janne Haaland Matlary seems to have expressed what modern women need in this respect, by writing in her book A Time to Blossom: Notes on a New Feminism that women are looking for solutions to practical problems in order to attain balance between work and maternity. The solutions that would make it possible for women to fulfil the role of mother, and at the same time achieve 
true professionalism in working life, exert influence on society and change it through political activity ${ }^{1}$.

Women's rights in the light of the Constitution of the Republic of Poland (RP) ${ }^{2}$

In analysing electoral programmes in respect of how they deal with the issue of women's rights, it is worth invoking the rights guaranteed in the most important legally binding act in Poland, namely the Constitution of the Republic of Poland dated 2 April $1997^{3}$. The guarantee of equality before the law, being a fundamental condition for anti-discrimination, can be found in Article 32 of the Constitution of the Republic of Poland, which stipulates that:

All persons shall be equal before the law. All persons shall have the right to equal treatment by public authorities. No one shall be discriminated against in political, social or economic life for any reason whatsoever.

The provision that directly regulates the problems of equality between women and men is Article 33 of the Constitution of the Republic of Poland, which states that:

Men and women shall have equal rights in family, political, social and economic life in the Republic of Poland. Men and women shall have equal rights, in particular, regarding education, employment and promotion, and shall have the right to equal compensation for work of similar value, to social security, to hold offices, and to receive public honours and decorations.

Moreover, equality between women and men is addressed in Article 18 of the Constitution of the Republic of Poland, worded as follows:

Marriage, being a union of a man and a woman, as well as the family, motherhood and parenthood, shall be placed under the protection and care of the Republic of Poland.

1 J. H. Matlary, Nowy feminizm. Kobieta i świat wartości [A Time to Blossom: Notes on a New Feminism], trans. M. Ratajczak, W drodze, Poznań 2000, p. 10.

2 Important in the context of the discussed issue are also provisions prohibiting discrimination and promoting equality between women and men that are contained in the legal system of the European Union. The main issues related to EU anti-discrimination law are described in the article: M. Lesińska - Staszczuk, Przeciwdziałanie dyskryminacji ze względu na pteć w świetle wybranych orzeczeń Trybunatu Sprawiedliwości Unii Europejskiej [in:] Dyskryminacja: przyczyny, przejawy, sposoby zapobiegania, M. Lesińska-Staszczuk, J. Wasil (ed.), UMCS, Lublin 2016, pp.13 - 30.

3 Constitution of the Republic of Poland, Dz. U. [Journal of Laws] of 1997, no. 78, item 483. 
It should be emphasised that the draft of the Constitution of the Republic of Poland of 1997 was consulted with several women's organisations and these put forward other versions of the cited articles. In compliance with the Convention on the Elimination of All Forms of Discrimination against Women ${ }^{4}$ and the Beijing Platform for Action ${ }^{5}$, activists from women's non-governmental organisations (i.a. the Women's Rights Centre) demanded that the text of the Constitution be complemented with regulations on the state supporting: partnership in the family, the possibility of divorce, a ban on domestic violence and violence against women, reverse discrimination and free procreation choice ${ }^{6}$. Feminist advocates also suggested that the quoted Article 18 of the Constitution should read:

The Republic of Poland shall guarantee, to all, the right to enter into marriage and dissolve it by divorce. Marriage shall be grounded on the equality of rights and duties, and the public authorities and institutions shall follow policy aimed at promoting a model of a family based on partnership.

Moreover, it was postulated to amend Article 32 of the Constitution by adding to the third section, the following wording:

However, legal norms and any other actions temporarily introducing disparate treatment in order to enforce the rule of equality shall not be regarded as discrimination, but actions for the sake of equal rights.

Advocates of women's rights also found it essential that the obligation of authorities and public institutions to follow a policy on preventing domestic violence and violence against women be included in Article 40 of the Constitution:

4 Convention on the Elimination of All Forms of Discrimination against Women of 18 December 1979, Dz. U. [Journal of Laws] of 1982, no. 10, item 71.

5 The Fourth World Conference on Women, held in Beijing in 4-15 September 1995, had the strongest impact on the development of women's rights. It mapped out the strategies of actions for equality, advancement and increase of the share of women in social, political and economic life. The final document of the conference, the Beijing Platform for Action, comprised 12 key areas for eliminating discrimination against women, i.a. women and poverty, education of women, women and health, violence against women, and women and the economy, cf. Pekińska Platforma Działania [Beijing Platform for Action], United Nations Information Centre in Warsaw, http://www.unic.un.org.pl/rownouprawnienie/platforma_dzialania.php [accessed: 12.10.2019].

6 E. Lisowska, Równouprawnienie kobiet i mężczyzn w społeczeństwie, SGH, Warsaw 2008, pp. $254-255$. 
No one may be subjected to torture or cruel, inhuman, or degrading treatment or punishment, be it by authorities, legal institutions and individuals. The application of corporal punishment shall be prohibited. Authorities and public institutions shall be obliged to carry out active policy designed at preventing violence in a family, violence against women in public and private life.

However, Article 40 of the Constitution of the Republic of Poland eventually got the following wording:

No one may be subjected to torture or cruel, inhuman, or degrading treatment or punishment. The application of corporal punishment shall be prohibited.

Moreover, women's organisation demanded that the Constitution regulate matters connected with reproductive freedom and with access to information and knowledge regarding the measures and methods of planning a family:

Women and men have freedom to decide about having a child, while authorities and public institutions create conditions for free reproductive decisions, including a guarantee of access to information and knowledge regarding the measures and methods of planning a family ${ }^{7}$.

In spite of numerous consultations held between the government and women's circles, none of the above-mentioned provisions was ultimately taken into account in the texts of basic law. Under the Constitution of the Republic of Poland, on the other hand, institutions were set up that can be contacted by a person whose constitutional freedoms or rights have been violated. In compliance with Article 79 of the Constitution of the Republic of Poland:

In accordance with principles specified by statute, everyone whose constitutional freedoms or rights have been infringed, shall have the right to appeal to the Constitutional Tribunal for its judgement on the conformity to the Constitution of a statute or another normative act upon which basis a court or organ of public administration has made a final decision on his freedoms or rights or on his obligations specified in the Constitution ${ }^{8}$.

7 Ibidem.

8 Przeciwdziałanie dyskryminacji w Polsce: Uwarunkowania prawne i instytucjonalne, G. Wrona (ed.), Ministry of Labour and Social Policy of the Republic of Poland, Warsaw 2010, p. 18. 
The Commissioner for Citizens' Rights, established by virtue of Article 80 of the Constitution of the Republic of Poland to uphold human rights and freedoms, can be addressed by anyone who feels discriminated:

In accordance with principles specified by statute, everyone shall have the right to apply to the Commissioner for Citizens' Rights for assistance in protection of his freedoms or rights infringed by organs of public authority.

The competencies of the Commissioner include instituting legal proceedings and participating in them, filing for cassation and filing a complaint in cassation with the Supreme Court or the Supreme Administrative Court, and making applications to the Constitutional Tribunal ${ }^{9}$.

Women's rights in the electoral programmes of individual political parties

In assessing the programmes of the parties victorious in the 2019 parliamentary elections in Poland, it should be stated that the majority did address socalled women's issues. Therein proposals were put forward that dealt with such problems as childcare, female health, equal pay for the same work irrespective of one's sex, an equal share of women and men in public authorities and effective counters to domestic violence.

The programmes of the following electoral committees were subject to evaluation ${ }^{10}$ :

- Electoral Committee of the Polish People's Party (PSL)

- Electoral Committee of Law and Justice (PiS)

- Electoral Committee of the Democratic Left Alliance (SLD)

- Electoral Committee of Confederation Liberty and Independence (KWiN)

- Coalition Election Committee Civic Coalition PO .N iPL Zieloni (KO)

As regards the first of the evaluated programmes, formulated by the Polish People's Party and titled "We Unite Poles", it does not touch upon many issues concerning women ${ }^{11}$. However, there are promises of improvements for families, expounded in the chapter "Family and Social Policy". Firstly, the number of crèches and children's clubs would be doubled. Secondly, the working time of parents of children under the age of 10 would be shortened by one hour (with pay

\footnotetext{
9 Ibidem.

${ }^{10}$ Individual programmes will be described according to the numbers assigned to the electoral committees by lot by the National Electoral Commission.

${ }^{11}$ Electoral programme of the Polish People's Party, https://www.psl.pl/psl-koalicja-polskaprzedstawia-nowy-program [accessed: 22.10.2019].
} 
retained). Thirdly, one of the parents would obtain a legal guarantee of work on a half-time basis for 12 months after parental leave, as well as financial support of PLN 1,000 per month during this time, irrespective of form of employment. Beyond the aforementioned, the declaration of support was made for the programme "Family 500 Plus" ${ }^{12}$ as well as the guarantee of keeping it up.

In the programme of the second of the registered electoral committees, Law and Justice, entitled "Polish Model of a Welfare State", more attention was paid to the issue of women ${ }^{13}$. First of all, the authors emphasised the need to continue existing policies for the sake of the most needy, to eliminate social divisions, to prevent the exclusion of various groups, and, most of all, to ensure the appropriate position of women in society.

The aforementioned programme devoted much attention to the family, which, in the party's opinion, has fallen victim to politics and to attempts to change its character. Law and Justice perceives the family as the most important element of the community, apart from the nation, and that the notion of family is based on a permanent relationship between a man and a woman. For this reason the party declares that it will carry on activity for strengthening the family, defending parenthood and stressing the special role of women as mothers and inspiring respect for maternity and paternity. These assumptions were reflected in such programmes as: "Family 500 Plus", "Toddler+" (which promotes the development of care institutions for children under 3), and the "Good Start" (whereby an annual benefit of PLN 300.00 is paid to all pupils beginning a school year). The appreciation of the role fulfilled by parents translated into the programme "Mum 4 Plus", a retirement benefit amounting to the minimum pension of PLN 1,100 , aimed at mothers (in some cases, also fathers) who resigned from gainful employment in order to raise four or more children.

What should be underscored in the party's programme is the significance attached to the role of religion, and the similarity between the Church's teachings and the national tradition discernible in the attitude towards the family.

The programme of Law and Justice gives close attention to the description of the differences between the earnings of women and men. The party clearly supports any actions aimed at equalising the remuneration between women and

12 The programme, being a financial support for families with two or more children, was initiated on 1 April 2016. In compliance with the changes introduced on 1 April 2019, each minor child is now entitled to the benefit, regardless of income gained by the family, Family 500 Plus, Ministry of Family, Labour and Social Policy of the Republic of Poland, https://www.gov.pl/ web/rodzina/rodzina-500-plus [accessed: 21.10.2019].

13 Electoral programme of Law and Justice, http://pis.org.pl/dokumenty [accessed: 21.10.2019]. 
men holding the same position. Simultaneously, it is emphasised that the gender pay gap exists not only in Poland, but is a global problem resulting from such phenomena as gender occupational segregation or a "glass ceiling" ${ }^{14}$.

The programme promises to support parents in combining their professional life with childcare by promoting flexible forms of employment, so that a parentfriendly environment, irrespective of the parent's sex, can be created. As part of help for young parents in their return to work, employers are to be encouraged to provide in-house nurseries and kindergartens. Furthermore, pregnant women should be taken special care of, being offered free medication during the whole gestation. As far as perinatal care is concerned, the party intends to reward maternity units that offer anaesthesia during childbirth.

In the electoral programme of the Democratic Left Alliance, titled "Poland of Tomorrow - the Main Postulates of the Left", a broad array of promises related to the women's rights can be found ${ }^{15}$. First of all, observance of the constitutional workers' rights was ensured, including the protection of parenthood by introducing fully paid and obligatory leave for both parents of a minimum length of 12 weeks, and by maintaining the programme "Family 500 Plus" and the "Baby Bonus" ${ }^{16}$. Moreover, the problem of the lack of places in nurseries and kindergartens was noticed and the creation of 200,000 new places in free nurseries in the following four years was promised.

The need to achieve equality between men and women was noticed also in relation to the gender pay gap and unequal representation in bodies of authority. For this reason, the Left is in favour of gender parity in the Council of Ministers, administration of districts, provinces, boroughs of Warsaw; as well as management boards and supervisory boards of local government companies and state-owned enterprises.

Much attention was paid to women's reproductive health. Firstly, safe abortion, dependent on a woman's decision up to the 12th week of pregnancy and, after the 12th week, justified by threat to women's life or health and grave foetus's defects, was pledged. Secondly, up-to-date contraceptives and full reimburse-

14 The phenomenon of a "glass ceiling" was defined for the first time in the US in the 1986 article published in the Wall Street Journal. It means invisible barriers such as prejudices, customs, or lack of network of contacts that limit promotion opportunities and mostly concern women, E. Lisowska, op. cit., p. 163.

15 Electoral programme of the Democratic Left Alliance, https://lewica2019.pl/program [accessed: 22.10.2019].

${ }^{16}$ One-time childbirth allowance in the amount of PLN 1,000, more about the requirements for receiving it at: Uzyskaj becikowe [Get the Baby Bonus], Polish Ministry of Digital Affairs, https://obywatel.gov.pl/zasilki-i-pomoc-finansowa/becikowe-jak-dostac [accessed: 20.10.2019]. 
ment of treatment for infertility by in vitro fertilization were promised. Thirdly, free medication for pregnant women and high standards of perinatal care, including access to anaesthesia, was to be assured ${ }^{17}$.

The following issues are also crucial from women's point of view: declaration of a secular state, abolition of the conscience clause and assurance of full availability of medical services and products in public medical facilities, irrespective of their staff's convictions.

Moreover, the left wing obliges itself to introduce modern education, responding to contemporary challenges and counteracting discrimination and violence, and an obligatory school subject dealing with human health and sexuality that is adjusted to the level of maturity of individual pupils. Besides the previous, the Left declares that it will help in the enforcement of due family support by treating it as tax arrears.

The programme of the next electoral committee, Confederation Liberty and Independence, namely "Poland for You", does not raise any issues concerning women's rights ${ }^{18}$. The programme also does not promise support for parents in combining their professional life with childcare. It only guarantees the rights of parents to bring up their children according to their values. Beyond this, opposition to sexual education, led by "self-appointed sex-educators and LGBT propagandists" was expressed.

As regards the last of the analysed programmes, that of the Coalition Election Committee Civic Coalition "Your Poland", it devotes much space to the issue of women's rights ${ }^{19}$. Firstly, the women's right to stress-free maternity that can be combined with professional work, was highlighted. A promise was also made to increase the number of places in nurseries and kindergartens and to introduce a 2-month paternity leave.

Secondly, the programme offered the adoption of solutions which would counter discrimination against women in the labour market, the equalisation of earnings of men and women possessing the same qualifications and carrying out work at the same positions, and introduction of a gender balance mechanism

${ }^{17}$ It should be stressed that the Left submitted a separate document on the women's rights, the so-called "Pact for Women". It contains ten points symbolising solutions that would guarantee equality between men and women, Konwencja Lewicy: "Pakt dla kobiet" - 10 rozwiązań na prawdziwą równość [The Convention of the Left: "Pact for Women" - 10 solutions for "true equality"], https://www.wprost.pl/wybory-parlamentarne-2019/10251008/konwencja-lewicypakt-dla-kobiet-czyli-10-rozwiazan-na-prawdziwa-rownosc.html [accessed: 21.10.2019].

${ }_{18}$ Electoral programme of Confederation Liberty and Independence, https://konfederacja. net/program [accessed: 22.10.2018].

19 Electoral programme of the Civic Coalition, https://koalicjaobywatelska.pl/program [accessed: 22.10.2019]. 
at directorial and managerial positions in public institutions and state-owned enterprises.

What is more, much attention was given to the issues related to reproductive health of women. An access to free in vitro fertilisation, prenatal diagnostic tests, perinatal care and free anaesthesia during childbirth was guaranteed. Introduction of sexual education at schools, as well as the reimbursement of contraceptives were put forward.

The programme of the Civic Coalition includes fierce opposition to domestic violence by e.g. amending the Polish Penal Code and providing assistance for single mothers in recovering overdue child support.

\section{Electoral programmes - juxtaposition}

On making an attempt at the comparison and description of the foregoing electoral programmes in respect of how they address women's issues, it should be stated that all the parties shared some promises, while others were present only in the programme of one or two parties. Furthermore, almost all of the examined parties recognised the important role of the state in supporting Polish families in bringing up children and combining parental duties with career. Therefore, each programme (except for that of Confederation) offers to increase the number of places in childcare facilities, in particular, for the youngest children, and to adjust working hours to parents' individual needs.

Actions facilitating the reconciliation of a career with nurturing children have become part of the European Commission's strategy of flexicurity - flexibility in the labour market combined with social security ${ }^{20}$. The aim of flexicurity is to guarantee employees a high level of employment security and to ensure that both employees and employers, to the greatest possible extent, take advantage of the opportunities afforded by globalisation. Flexicurity literally means an integrated strategy of simultaneously increasing flexibility and security within the labour market ${ }^{21}$.

While designing and implementing the policy of flexicurity, the following components should be taken into consideration:

${ }^{20}$ Communication from the Commission to the Council, the European Parliament, the Economic and Social Committee and the Committee of the Regions. Mid-term progress report on the roadmap for equality between women and men (2006-2010), COM(2008) 760 final, 26 November 2008.

${ }^{21}$ Communication from the Commission to the European Parliament, the Council, the European Economic and Social Committee and the Committee of the Regions. Towards Common Principles of Flexicurity, COM(2007) 359 final, 27 June 2007. 
- offer of flexible and reliable contractual arrangements, made on the basis of modern labour law, collective agreements and work organisation,

- implementation of comprehensive lifelong learning strategies, which allow the weakest social groups to adjust to the changing labour market,

- enaction of effective and active labour market policies that help people to cope with periods of unemployment and to facilitate employment transitions.

- provision of modern social security systems that foster employment and mobility on the labour market ${ }^{22}$.

The above-listed elements should back up each other, improving the employment rate in, above all, high-risk groups, i.e. women, young people and the elderly.

What is clearly evident is that all the programmes stress the role of the family in society, mutual influences between the private and public sphere, and the influence of a family situation on women's job-related decisions. This indicates how important it is for the state to conduct policies that take these aspects into account ${ }^{23}$.

Equal payment for women and men working at the same position is a promise included in the programmes of Law and Justice, the Democratic Left Alliance and the Civic Coalition. Although Poland comes out well in comparison with other EU member states, with the difference in salaries between men and women amounting to $7.2 \%$ (the EU average equals 16.2\%), there is still much to be done in this respect. Gender-related factors influencing the amount of remuneration embrace i.a. quicker promotion of men to managerial positions and the fact that women usually do unpaid domestic work, such as care of children or the elderly ${ }^{24}$.

The greatest attention to the reproductive health of women was given in the programmes of the Civic Coalition and the Democratic Left Alliance. Apart from the assurance of high standards of perinatal care and anaesthesia during childbirth, as well as reimbursement of modern contraceptives and in vitro fertilisation, the programme of the Civic Coalition promises full access to prenatal testing, while the programme of the Left offers access to legal abortion. Under applicable law it is allowed to terminate pregnancy when it endangers woman's life or health; prenatal diagnostic tests or other medical premises indicate that there is a high probability of a serious and irreversible malformation of the foetus or an incurable illness threatening its life; and there is a justified suspicion that

22 Ibidem.

23 E. Lisowska, op. cit., p. 98.

24 The gender pay gap in Poland, European Commission, http://ec.europa.eu/justice/gender-equality/gender-pay-gap/index_en.htm [accessed: 23.10.2019]. 
the pregnancy is a result of a criminal act ${ }^{25}$. In this context it seems crucial to mention the pledge, given by the Left, to do away with the conscience clause, which is referred to by doctors refusing to carry out abortion,

The idea of separating State and Church always engenders heated controversy in electoral programmes. Taking into consideration the analysed programmes, two extreme approaches can be found: the Left puts forward complete separation of the Catholic Church and the state, while Law and Justice emphasises the paramount role of the Church in building Polish society.

Only two electoral committees, the Civic Coalition and the Democratic Left Alliance, obliged themselves to get involved in countering domestic violence, and although the social awareness of this phenomenon has increased, it still remains an essential problem experienced mainly by women. In the light of the Istanbul Convention (anti-violence) ${ }^{26}$, ratified by Poland, "domestic violence" means "all acts of physical, sexual, psychological or economic violence that occur within the family or domestic unit". The Convention notes that such acts of violence can be done both between former or current spouses or partners, regardless of their place of residence ${ }^{27}$. According to estimates, of the two genders, women for the most part are the ones who fall victim to violence. Indeed, compiled statistics reveal that every third woman over the age of 15 has experienced physical or mental violence in her life ${ }^{28}$. It should be remembered that violence against women constitutes one of the crucial manifestations of human rights abuse and perpetuation of inequalities in the family and society ${ }^{29}$.

25 Act on Family Planning, Human Embryo Protection and Conditions of Permissibility of Abortion of 7 January 1993, Dz. U. [Journal of Laws] of 1993, no. 17, item 78.

${ }^{26}$ Convention on preventing and combating violence against women and domestic violence, https://rm.coe.int/168008482 [accessed: 25.10.2019].

27 What is most unclear is extending the notion of domestic violence to include economic violence and acts of aggression perpetrated by ex-spouses and former partners. Cf. Polska wolna od przemocy wobec kobiet: Wybrane problemy dotyczące wdrożenia konwencji o zapobieganiu i zwalczaniu przemocy wobec kobiet i przemocy domowej [Poland Free from Violence against Women: Selected Problems Relating to the Enforcement of the Convention on Preventing and Combating Violence against Women and Domestic Violence], Amnesty International, https:// amnesty.org.pl/wp-content/uploads/2018/02/Polska-wolna-od-przemocy-wobec-kobiet_analiza_Amnesty-International-2.pdf [accessed: 21.10.2019].

${ }^{28}$ Data for the EU - 28 states, Violence against women, EU Agency for Fundamental Rights, https://fra.europa.eu/sites/default/files/fra-2014-vaw-survey-factsheet_pl.pdf [accessed: 18.10.2019].

${ }^{29}$ E. Lisowska, op. cit., p. 123.0 


\section{Final remarks}

Women's rights are an ever-present issue in public discourse on the Polish family, the birth and upbringing of children, broadly understood reproductive health and the gender employment gap. Almost all the parties that won representation in the 2019 parliamentary elections put forward proposals of actions and recognized the need for amendments to legal provisions. However, it should be remembered that law is only a tool in combating inequalities between women and men and ensuring them due health care and the safety jeopardised by perpetrators of domestic violence. Apart from new legal regulations, what is necessary are institutions upholding such laws and, most importantly, people working in these institutions, who respect human dignity, demonstrate empathy and treat others with respect.

\section{Bibliography}

- Act on Family Planning, Human Embryo Protection and Conditions of Permissibility of Abortion of 7 January 1993, Dz. U. [Journal of Laws] of 1993, no. 17, item 78.

- Communication from the Commission to the Council, the European Parliament, the Economic and Social Committee and the Committee of the Regions. Mid-term progress report on the roadmap for equality between women and men (2006-2010), COM (2008) 760 final, 26 November 2008.

- Communication from the Commission to the European Parliament, the Council, the European Economic and Social Committee and the Committee of the Regions. Towards Common Principles of Flexicurity, COM (2007) 359 final, 27 June 2007.

- Constitution of the Republic of Poland, Dz. U. [Journal of Laws] of 1997, no. 78, item 483.

- Convention on preventing and combating violence against women and domestic violence, https://rm.coe.int/168008482 [accessed: 25.10.2019].

- Convention on the Elimination of All Forms of Discrimination against Women of 18 December 1979, Dz. U. [Journal of Laws] of 1982, no. 10. item 71.

- Data for the EU - 28 states, Violence against women, EU Agency for Fundamental Rights, https://fra.europa.eu/sites/default/files/fra-2014-vaw-survey-factsheet_pl.pdf [accessed: 18.10.2019].

- Electoral programme of Confederation Liberty and Independence, https://konfederacja.net/program [accessed: 22.10.2018].

- Electoral programme of Law and Justice, http://pis.org.pl/dokumenty [accessed: 21.10.2019].

- Electoral programme of the Civic Coalition, https://koalicjaobywatelska.pl/program [accessed: 22.10.2019].

- Electoral programme of the Democratic Left Alliance, https:/lewica2019.pl/program [accessed: 22.10.2019]. 
- Electoral programme of the Polish People's Party, https://www.psl.pl/psl-koalicjapolska-przedstawia-nowy-program [accessed: 22.10.2019].

- Family 500 Plus, Ministry of Family, Labour and Social Policy of the Republic of Poland, https://www.gov.pl/web/rodzina/rodzina-500-plus [accessed: 21.10.2019].

- Konwencja Lewicy: "Pakt dla kobiet" - 10 rozwiązań na prawdziwą równość [The Convention of the Left : "Pact for Women" - 10 solutions for "true equality"], https:// www.wprost.pl/wybory-parlamentarne-2019/10251008/konwencja-lewicy-pakt-dlakobiet-czyli-10-rozwiazan-na-prawdziwa-rownosc.html [accessed: 21.10.2019].

- Lesińska - Staszczuk M., Przeciwdziałanie dyskryminacji ze względu na pteć w świetle wybranych orzeczeń Trybunatu Sprawiedliwości Unii Europejskiej [in:] Dyskryminacja: przyczyny, przejawy, sposoby zapobiegania, M. Lesińska-Staszczuk, J. Wasil (ed.), UMCS, Lublin 2016.

- Lisowska E., Równouprawnienie kobiet i mężczyzn w społeczeństwie, SGH, Warsaw 2008.

- Matlary J. H., Nowy feminizm. Kobieta i świat wartości [A Time to Blossom: Notes on a New Feminism], trans. M. Ratajczak, W drodze, Poznań 2000.

- Pekińska Platforma Działania [Beijing Platform for Action], United Nations Information Centre in Warsaw, http://www.unic.un.org.pl/rownouprawnienie/platforma_dzialania.php [accessed: 12.10.2019].

- Polska wolna od przemocy wobec kobiet: Wybrane problemy dotyczące wdrożenia konwencji o zapobieganiu i zwalczaniu przemocy wobec kobiet i przemocy domowej [Poland Free from Violence against Women: Selected Problems Relating to the Enforcement of the Convention on Preventing and Combating Violence against Women and Domestic Violence], Amnesty International, https://amnesty.org.pl/wp-content/ uploads/2018/02/Polska-wolna-od-przemocy-wobec-kobiet_analiza_Amnesty-International-2.pdf [accessed: 21.10.2019].

- Przeciwdziatanie dyskryminacji w Polsce: Uwarunkowania prawne i instytucjonal$n e$, G. Wrona (ed.), Ministry of Labour and Social Policy of the Republic of Poland, Warsaw 2010.

- The gender pay gap in Poland, European Commission, http://ec.europa.eu/justice/ gender-equality/gender-pay-gap/index_en.htm [accessed: 23.10.2019].

- Uzyskaj becikowe [Get the Baby Bonus], Polish Ministry of Digital Affairs, https://obywatel.gov.pl/zasilki-i-pomoc-finansowa/becikowe-jak-dostac [accessed: 20.10.2019].

Summary: Women's rights in the 21st century are an ever-present issue in public debate and are often reflected in the electoral programmes of individual political parties. Both the right and the left side of the political scene promise equal rights of women and men in public life, counteraction of discrimination in respect of employment, support for families and provision of adequate health care. Upon examining the programmes of the parties that won representation in the 2019 parliamentary elections in Poland, it should be stated that the majority did address so-called women's issues. Included in the portfolio of most party platforms were ways and means of dealing with such problems as: childcare, female health, equal pay for the same work irrespective of 
one's sex, equal share of women and men in positions of public authority and effective counters to domestic violence.

Keywords: women's rights, anti-discrimination, party programmes, parliamentary election in Poland

Prawa kobiet w świetle programów zwycięskich partii politycznych w wyborach parlamentarnych w Polsce w 2019 r.

Streszczenie: Problematyka praw kobiet w XXI wieku jest stale obecna w debacie publicznej i znajduje odzwierciedlenie w programach wyborczych poszczególnych partii politycznych. Zarówno po prawej, jak i po lewej stronie sceny politycznej znajdziemy postulaty dotyczące równouprawnienia kobiet i mężczyzn w życiu publicznym, przeciwdziałania dyskryminacji w zatrudnieniu, wsparcia dla rodzin czy należytej opieki zdrowotnej. Analizując programy zwycięskich partii politycznych w wyborach parlamentarnych w 2019 r. w Polsce, należy stwierdzić, że większość z nich podjęła tzw. problematykę kobiecą. Kwestie te dotyczyły takich zagadnień jak: opieka nad dziećmi, zdrowie kobiet, ale też równa płaca za pracę tej samej wartości bez względu na płeć, równy udział kobiet i mężczyzn we władzach publicznych czy skuteczna walka z przemocą domową.

Słowa kluczowe: prawa kobiet, przeciwdziałanie dyskryminacji, programy partyjne, wybory parlamentarne w Polsce 